\title{
Students' Ability to Construct Negotiated Text: A Text and Context Study in Tenth Grade Students at Vocational High School Prayatna 1 Medan 2020-2021 Academic Year
}

\author{
Mayang Sari Mustika Ratu ${ }^{1}$, Rahmat Kartolo ${ }^{2, *}$, Radhitullah ${ }^{1}$, Sari Sukawati ${ }^{1}$, \\ Trisnawati Siregar ${ }^{1}$, and May Narlin ${ }^{1}$
}

${ }^{1}$ Postgraduate of Universitas Muslim Nusantara Al Washliyah Medan, Indonesia

${ }^{2}$ Lecturer of Universitas Muslim Nusantara Al Washliyah Medan, Indonesia

*Corresponding author email: rahmatkartolo@umnaw.ac.id

\begin{abstract}
This research is aimed at describing the extent to which students' abilities in constructing negotiation texts. This research was conducted at Prayatna 1 Medan Vocational High School in 2020-2021 academic year. The sample of the study was 32 people who were taken randomly from 174 students. The research method used was descriptive method. The instrument used was an objective test, namely a test to construct a negotiating text. The results of research conducted at Prayatna 1 Medan Vocational High School showed that the average construction ability obtained was 77.53 and it was included in the good category with $31 \%$ of students getting very good scores, $44 \%$ good categories, $22 \%$ categories enough and 3\% category less. The aspect that received the highest score was the aspect of accuracy in linking the content with the theme which received an average of 93.75 with $87.5 \%$ getting a perfect score. While the aspect with the lowest score is the aspect of content suitability with linguistic characteristics with an average of only 53.12 with $6.25 \%$ of students who get perfect scores. From this study it can be concluded that the ability to construct negotiation text of students at Prayatna 1 Medan Vocational High School academic year 2020-2021 is good.
\end{abstract}

Keywords: Negotiation Text, Ability, Constructing

\section{INTRODUCTION}

Language is often seen as a means of communication in conveying human thoughts and feelings. This statement shows the importance of language in human life. Therefore, humans must learn and understand language which has an important role in the Indonesian state. Realizing the importance of the role of Indonesian language, the government has determined Indonesian as a compulsory subject that is taught at all school levels with the aim that Indonesian can be used and mastered properly and correctly in various communication activities [1]-[5]. Teaching Indonesian language has the scope and purpose of fostering the ability to express thoughts and feelings by using good and correct language. In essence, Indonesian learning is directed to sharpen the sensitivity of students' feelings. In the 2013 revised 2016 curriculum, there are several competencies that must be mastered by students in the learning process. One of these competencies is constructing the negotiating text. Constructing the negotiation text is found in KI (Kompetensi Inti) No. 4, especially KD (Kompetensi Dasar) No. 4.11. Namely constructing the negotiating text by paying attention to its content, structure, and language characteristics.

According to Kosasih [6], negotiation is a form of social interaction that functions to reach agreement between parties who have different interests. Negotiation is a joint decision-making process between several parties with 
different interests. Negotiation is a way of determining a decision that can be agreed upon by two or more parties to meet the satisfaction of the parties concerned.

The general understanding of constructing a negotiation text is making a text that contains language bargaining to reach an agreement between two parties by paying attention to the structure and characteristics of the language. Learning to construct the negotiating text itself is one of the materials contained in Senior High School or Vocational High School in tenth grade semester 2.

Kosasih [6] suggests that negotiation skills are important for us to master in order to achieve certain goals. For that negotiation has a goal, namely to produce an agreement, produce mutually beneficial decisions, and lead to practical goals. When there is an activity, purpose or desire that involves other people, we should always be winners. Negotiating conversation is key.

According to the Indonesian teacher at Vocational High School Prayatna 1 Medan, the students' weak writing ability is not only related to the strategies and learning models applied in the learning process. Various conditions cause the low ability to write negotiation texts, including the low understanding of the structure and characteristics of language. The low understanding of the structure and characteristics of the language of the text is due to the fact that the material is still newly applied. There are still many students who are confused and even don't understand the structure of the text, linguistic characteristics, and the use of Indonesian spelling in writing negotiating texts. Therefore, writing or constructing is called a productive and expressive activity [7]-[13].

However, in reality, this writing activity is very difficult for most students to do, especially writing negotiation texts. Even limited by a theme, some students still have difficulty linking their essay text with the chosen theme. This is known from the results of interviews with Indonesian language subject teachers at Vocational High School Prayatna 1 Medan who stated that the average score of students for Indonesian was still low, namely from 32 students of class X AP 2, 72\% or as many as 23 students scored below. KKM (less than 75), while the remaining $28 \%$ or as many as 9 students scored above the KKM (more than 75). Based on these data, students in these schools have not been able to make negotiation texts properly and correctly.

The ability of students in writing negotiation texts which were stated to be still incapable was also supported by a study conducted by Suryani et al. [14], which stated that the results of the study showed the ability students in writing negotiation texts are still not able to, namely with an average score of students under the KKM 8.00. Therefore, these students must be given a remedial.

Based on the above background, it is necessary to carry out a study to see how students' ability to construct negotiation texts in the field of text and context studies. In this case, the problem held to overshadow this research is "Students' Ability to Construct Negotiated Text: A Text and Context Study in Tenth Grade Students at Vocational High School Prayatna 1 Medan 2020-2021 Academic Year".

The researchers conducted research on the ability to construct because they wanted to get a picture of students' abilities in constructing negotiation texts. The aim of the researchers conducted research on the ability to construct negotiating texts was to describe the ability to construct negotiation text and equip students to be able to correct mistakes in constructing negotiation texts and so that students could skilled in constructing negotiation texts.

\section{METHODOLOGY}

This research was conducted at Prayatna 1 Medan Vocational High School. The research method chosen was closely related to the procedures, tools and research design used. Therefore, the research method used in this research is descriptive method for quantitative type, the use of descriptive method by the researcher is to describe how the students' ability in constructing negotiation text is seen from the structure of the text itself. The use of quantitative research forms intended in this study is to obtain average data on students' ability to construct negotiation texts.

This study has one independent variable, namely the ability to construct negotiation text in tenth grade of students at Vocational High School Prayatna 1 Medan by paying attention to the building blocks. The data taken in this study are the test results of constructing the negotiating text that have been given to the research sample.

The instrument used in this research is the essay test. The essay test referred to in this research is a test to construct a negotiation text by paying attention to the context, structure, theme and linguistic characteristics of the text.

\section{RESULTS AND DISCUSSION}

\subsection{Results}

The data of this research is the ability to construct negotiation text of the tenth-grade students of Vocational High School Prayatna 1 Medan. The assessment of the research data was the score of the assessment aspect consisting of context (max. 4), structure (max. 4), the suitability of the content with linguistic characteristics (max. 4), and the accuracy of the content with the theme (max. 4).

Based on the data on the value of the ability to construct negotiation text for students at Vocational High School Prayatna 1 Medan, if we look at the percentage of students in the value of the ability to construct negotiation text according to Nurgiyantoro [15], as follows. 
Table 1. Data Frequency Ability to Construct Negotiation Text by Students at Vocational Prayatna 1 Medan

\begin{tabular}{lccc}
\hline \multicolumn{2}{c}{ Value } & Frequency & Percentage \\
\cline { 1 - 2 } Qualitative & Quantitative & & \\
\cline { 1 - 3 } Very Good & $86-100$ & 10 & $31 \%$ \\
Good & $70-85$ & 14 & $44 \%$ \\
Enough & $56-69$ & 7 & $22 \%$ \\
Less & $10-55$ & 1 & $3 \%$ \\
\cline { 1 - 3 } Total & & $32(100 \%)$ & $100 \%$ \\
\hline
\end{tabular}

The average value of the ability to construct negotiation text students at Vocational High School Prayatna 1 Medan is as follows:

$$
M x=\frac{\Sigma X}{N}=\frac{2481.25}{32}=77.53 \approx 78 .
$$

So, the average ability of students at Vocational High School Prayatna 1 Medan is 77.53 and if it is rounded up to 78 . If this average score is included in the classification of the value of the ability to construct a negotiating text, then the mean value is included in the category good. In other words, the tenth-grade students are quite capable of constructing a negotiating text.

\subsection{Discussion}

Based on the results of the study, the description or findings that the ability to construct negotiation text by Vocational High School Prayatna 1 Medan 2020-2021 academic year with an average value of 77.53 can be categorized as good. This is evidenced by the percentage value in each aspect of the assessment constructing the negotiating text namely 1) the accuracy of the text based on the context obtains a score of 80.46 in the good category, 2) the completeness of the structure obtains an average score of 82.81 is in the good category, 2) the suitability of the content with linguistic characteristics gets a score of 53.12 is in the poor category, 3) the ability to link the content of the negotiating text with the theme gets an average score of 93.75 is in the very good category. Of the four aspects assessed in constructing the negotiating text, it is known that the aspects relating the content of the text to the theme obtained the highest average score with an average of 93.75 with 28 students with a percentage of $87.5 \%$ who got perfect scores. Students do not find it difficult to relate the contents of their negotiating text to a predetermined theme (buying and selling). This is because a theme is the most common element found in any essay so that adapting the content of the text to a particular theme is not difficult for students to do.

After the aspect of linking the content of the text with the theme becomes the aspect with the highest score, then the score that ranks second highest is the aspect of understanding the structure of the negotiating text obtaining an average score of 82.81. On the aspect of understanding the structure. The value mentioned above falls into the good category. Then the aspect of text accuracy based on context obtained an average value of 80.46. This value falls into the good category.

The next aspect is the aspect that is least mastered by students, namely the aspect of content suitability with linguistic characteristics which only gets an average score of 53.12 with only 2 students who get perfect scores. This value falls into the poor category, so this shows that this aspect is the obstacle for students to write negotiation texts properly and correctly. Most of them only wrote one or two linguistic characteristics, namely 9 students only entered one linguistic characteristic and 13 students entered two linguistic characteristics, whereas there should be many features that could be included in the negotiation text such as words of appreciation, logical reasons, persuasion and so on.

Based on the percentage or the results of the student's ability to construct the negotiation text through the explanation above, it is clear that the student's ability to construct the negotiation text can be said to be good, because the average score is in the good category. However, teachers are still encouraged to improve the teaching and learning process in learning to construct texts, especially negotiation texts, because there are still deficiencies in certain aspects.

\section{CONCLUSION}

Based on the research results that have been described above, it can be concluded that the ability to construct negotiation text of students at Vocational High School Prayatna 1 Medan Tembung District, North Sumatra Province is good. This can be seen through the students' average score in constructing the negotiating text as a whole, which is good (77.53). In terms of the percentage, students who scored in the very good category were 10 people or $31 \%$, the good category was 14 people or $44 \%$, the enough category was 7 people or $22 \%$ and the less category was 1 person or $3 \%$.

The aspect in constructing the negotiation text that has the lowest average score is the aspect of adjusting the content with linguistic characteristics which gets an average of 53.12 with only 2 students who get perfect (very good) scores. This is because entering several characteristics into a text is enough to make it difficult for students to remember it will increase the quantity of the content of 
the negotiating text, while many students only make the negotiation text briefly.

The ability to write negotiation texts by students is good enough, but this is not a benchmark for slowing down or stopping the improvement of the quality of text learning, especially negotiation texts. Therefore, the author suggests teachers to further develop students' abilities in negotiating text material with innovative practices or teaching materials. To students, the author suggests to be more active in studying text material in Indonesian, especially negotiation texts because writing text is one of the main subjects in Indonesian language learning.

\section{REFERENCES}

[1] T. Hutagalung, D. E. Sari, A. Wasilah, The Effectiveness of E-Learning on Students in the Teaching of Children's Literature Subject in Indonesian Language and Literature Study Program. Budapest International Research and Critics Institute (BIRCIJournal): Humanities, 1 (4) (2018), 277-281.

[2] D. Zuchdi, Nurhadi, Culture Based Teaching and Learning for Indonesian As A Foreign Language in Yogyakarta. Cakrawala Pendidikan, 38 (3) (2019), 465476.

[3] I. Gunawan, Indonesian Curriculum 2013: Instructional Management, Obstacles Faced by Teachers in Implementation and the Way Forward. 3rd International Conference on Education and Training (ICET 2017), Advances in Social Science, Education and Humanities Research, 128 (2017), 56-63.

[4] M. Irmalia, Indonesian interference in students' writing. English Education Journal, 7 (4) (2016), 496508 .

[5] I. P. M. Dewantara, I. N. Suandi, I. W. Rasna, I. B. Putrayasa, Cultivating Students' Interest and Positive Attitudes towards Indonesian Language through Phenomenon-Text-Based Information Literacy Learning. International Journal of Instruction, 12 (2) (2019), 147-162.

[6] E. Kosasih, Jenis-jenis Teks. Yogyakarta: Gava Media, 2017.

[7] N. Habibah, T. A. Siburian, M. O. F. Gafari, Development of Writing Teaching Material of Negotiation Text Based on Experience of Students Class X MAN 2 Model Padangsidimpuan. International Journal of Education, Learning and Development, 6 (6) (2018), 35-46.
[8] I. Zohar, The art of negotiation: Leadership skills required for negotiation in time of crisis. Procedia Social and Behavioral Sciences, 209 (2015), 540-548.

[9] C. Alavoine, F. Kaplanseren, F. Teulon, Teaching (And Learning) Negotiation: Is There Still Room For Innovation?. International Journal of Management \& Information Systems, 18 (1) (2014), 35-40.

[10] J. Matos, International Negotiation Competitions: Benefits and Adaptability to the Humanitarian Sector. Master Thesis in Humanitarian Action and Conflict, Department of Theology, Uppsala University, 2018.

[11] P. Põlajeva, Business Negotiations: Communication in The Bargaining Process. Journal of Business Economics and Management, 18 (3) (2017), 554-559.

[12] N. Radani, T. Hutagalung, The Ability to Write Negotiated Text on Multimedia Grade X Students of SMKN 10 Medan in Academic Year 2019/2020. Jurnal Pendidikan Bahasa dan Sastra Indonesia, 3 (2) (2020), 110-126.

[13] R. P. S. Ritonga, T. A. Siburian, Ambarita, PostTest Learning Result After Using Teaching Learning on Negotiation Text Based on Problem for X Grade Students at Senior High School 19 Medan. British Journal of English Linguistics, 5 (5) (2017), 1-12.

[14] P. Suryani, Pembelajaran Bahasa Indonesia Berbasis Teks di Kelas X SMA Negeri 1 Singaraja. Jurnal Pendidikan Bahasa dan Sastra Indonesia, 2 (1) (2014).

[15] B. Nurgiyantoro, Penilaian Otentik dalam Pembeljaran Bahasa. Yogyakarya: Gajah Mada University Press, 2015. 